УДК 351:35:323.2

DOI: https://doi.org/10.32782/2520-2200/2019-6-18

Загорянська О.Л.

кандидат економічних наук, доцент, Кременчуцький національний університет імені Михайла Остроградського

Сосновська Ю.Р. магістр з туризму

Кременчуцького національного університету імені Михайла Остроградського

Zahorianska Olena

Kremenchuk Mykhailo Ostrogradskyi University

Sosnovska Yuliia

Kremenchuk Mykhailo Ostrogradskyi University

\title{
ДЕРЖАВНЕ УПРАВЛІННЯ РЕГІОНАЛЬНИМ РОЗВИТКОМ ТУРИЗМУ: ПРОБЛЕМИ ТА ШЛЯХИ ВИРІШЕННЯ
}

\section{STATE GOVERNANCE OF REGIONAL TOURISM DEVELOPMENT: PROBLEMS AND WAYS OF SOLUTION}

\begin{abstract}
У статті проведено аналіз туристичного потенціалу України на прикладі Полтавської області, визначено структуру та функції державного управління регіональним розвитком туризму, досліджено становлення органу державного регулювання в сфері туризму України, обґрунтовано позитивні та негативні фактори впливу на розвиток туристичної галузі, проаналізовано туристичні потоки в Полтавській області, проведено SWOT-аналіз туристичної галузі Полтавської області, визначено проблеми, розроблено стратегічні рекомендації щодо вдосконалення державного регулювання розвитку туризму та стимулювання його фрінансово-ресурсного забезпечення в регіонах України.
\end{abstract}

Ключові слова: державне регулювання, регіональна політика, туристичний потенціал, туристичні потоки, туристична галузь, SWOT-аналіз.

В статье проведен анализ туристического потенциала Украины на примере Полтавской области, определены структура и функции государственного управления региональным развитием туризма, исследовано становление органа государственного регулирования в сорере туризма Украины, обоснованы положительные и отрицательные факторы влияния на развитие туристической отрасли, проанализированы туристические потоки в Полтавской области, проведен SWOTанализ туристической отрасли Полтавской области, определены проблемы, разработаны стратегические рекомендации по совершенствованию государственного регулирования развития туризма и стимулирования его фринансово-ресурсного обеспечения в регионах Украины.

Ключевые слова: государственное регулирование, региональная политика, туристический потенциал, туристические потоки, туристическая отрасль, SWOT-анализ.

The aim of the research is analyze the tourism potential, identify problems and develop strategic recommendations for improving state regulation of tourism development and stimulating its financial and resource provision in the regions of Ukraine, on the example of the Poltava region. The structure and functions of state management of regional tourism development are determined; the positive and negative factors of influence on the tourism industry development are substantiated. The scale and economic efficiency of the functioning of the tourism industry of the state depend largely on the organic combination of self-government and economic activity of the subjects of tourism activity on the one hand and coordination and management activity at the national-sectoral and regional-sectoral levels on the other. Strengthening market relations in Ukraine occurs through the formation and development of a mixed economy, where market and state regulation interact, in particular at the regional level. One of the main directions of development of economy of regions of the country the state defines tourism. The structure of tourism management in Ukraine was generalized. The formation of the state regulatory body in the sphere of tourism of Ukraine is analyzed. An example of the restrained development of tourism in the presence of various tourist and recreational potential is the Poltava region. The data given in 
the article show that there are some positive changes in the economy of the region, which have affect, the development of tourism potential. Ukraine has chosen as its strategic course integration into the structures of the European Union. To achieve this goal, a number of conditions must be fulfilled, one of the most important being active regional development. Thus, problems were identified and strategic recommendations were developed to improve state regulation of regional tourism development in Poltava region.

Key words: state regulation, regional policy, tourism potential, tourist flows, tourism industry, SWOT analysis.

Постановка проблеми. Вітчизняний туристичний бізнес, який складається з рекреації й туризму, є невід'ємною частиною світового туристичного процесу. Попри всі політичні та соціально-економічні негаразди останніх років. індустрія туризму стала тією галуззю народного господарства України, яка до економічної кризи з року в рік без залучення державних дотацій мала стабільну тенденцію збільшення обсягів виробництва туристичного продукту. До сфрери туризму входить безліч суміжних галузей економіки (транспорт, зв'язок, харчування тощо), тому очевидною $\epsilon$ проблема узгодження їхнього злагодженого функціонування, якого можна досягти виключно шляхом ефективного державного регулювання та управління [1].

Міжнародний досвід розвитку туризму свідчить про те, що майже всі країни світу використовують сполучення ринкових механізмів господарювання 3 державним регулюванням цього виду діяльності. У багатьох країнах світу державні органи надають значну підтримку туристичному сектору економіки, що виявляється в таких формах, як виділення бюджетних коштів на фрінансування програм розвитку туризму, створення сприятливого інвестиційного клімату й зниження ставок по кредитах для будівництва та модернізації матеріальнотехнічної бази туризму [2]. Отже, кожна країна, яка визначає туризм одним з пріоритетних напрямів розвитку економіки, повинна впроваджувати політику стимулювання туристичного бізнесу на державному рівні, регулювати ринкову діяльність у туризмі щодо суспільних інтересів за допомогою прийняття необхідних законодавчих актів, координувати роботу всіх міністерств та відомств для підвищення якості надання туристичних послуг.

Аналіз останніх досліджень і публікацій. Вивченню проблем ефрективного розвитку туристичної галузі й дослідженню перспектив регулювання діяльності підприємств вітчизняної туристичної індустрії присвячені праці багатьох вітчизняних та зарубіжних авторів. Окремі аспекти регулювання розвитку туризму висвітлені в працях Ю.В. Алексєєвої [3], І.В. Бережної [4]. Проблеми розроблення управлінського механізму у сорері туризму розглядаються в роботах М.І. Круглова [5], С.П. Фокіна [6], О.Л. Загорянської [7]. Окремі аспекти регулювання розвитку туризму регіонів висвітлені в працях таких науковців, як В.К. Бабарицька [8], І.В. Валентюк [9], Л.М. Сакун [10].

Попри наявність розробок як теоретичного, так і науково-практичного характеру, залишаються недостатньо вивченими окремі аспекти державного регулювання та управління цією галуззю на рівні регіону. Це зумовило актуальність дослідження.

Метою статті $\epsilon$ аналіз туристичного потенціалу, визначення проблем та розроблення стратегічних рекомендацій щодо вдосконалення державного регулювання розвитку туризму та стимулювання його фінансово-ресурсного забезпечення в регіонах України на прикладі Полтавської області.

Виклад основного матеріалу дослідження. Світовий досвід регіонального розвитку свідчить про те, що в сучасному світі не існує якоїсь домінуючої моделі державного регулювання регіонального розвитку туризму. Саме в цій ссрері розходження між країнами особливо великі, що є прямим наслідком регіонального різноманіття. Зміцнення ринкових відносин в Україні відбувається шляхом формування й розвитку змішаної економіки, де взаємодіють ринкове й державне регулювання, зокрема, на регіональному рівні. Від ефективності державного регулювання розвитку різних сфер економіки залежить швидкість її трансформації до стандартів ЄС. Це повною мірою стосується сфери послуг туризму, роль та значення якої неухильно зростає завдяки створенню соціально орієнтованої ринкової економіки.

Ефективне функціонування туризму в країні або окремих регіонах є можливим тільки за наявності відповідної державної підтримки, різнорідні прояви якої об'єднані в організаційний блок. Він включає правове забезпечення діяльності туризму: від закону про туристичну діяльність до налагодження митної та консульської служби; створення сприятливих економічних умов, зокрема системи валютного обміну, страхування, оподаткування суб'єктів туристичної діяльності, проведення спеціальних наукових досліджень для туризму та створення розгалуженої мережі підготовки кадрів [10]. 
Незважаючи на те, що Україна має потужний туристично-рекреаційний потенціал, існує низка фракторів, які перешкоджають його розвитку, зокрема відсутність єдиного механізму державного регулювання туристичним сектором економіки; невідповідність нормативноправового та організаційно-фрінансового забезпечення сучасним тенденціям розвитку туризму; недостатність методичної та організаційної підтримки туристичної галузі, невеликі обсяги інвестицій у розвиток матеріальної бази; технологічна відсталість галузі. В Україні практично не застосовують туристичні технології, які в розвинених країнах набули ознак повсякденності, а саме електронні інформаційні довідники щодо готелів, транспортних маршрутів і туристичних фірм з переліком і вартістю послуг, які ними надаються.

У період сьогодення Україна, вибравши курс на Євроінтеграцію, зобов'язана виконувати умови Декларації про регіоналізм у Європі, в якій визначається головна умова, а саме активний розвиток регіонів за рахунок туристичної галузі. Регіональні відмінності в економічному та організаційному аспектах сприяють цьому розвитку або затримують його [10].

Прикладом стриманого розвитку туризму за наявності різноманітного туристично-рекреаційного потенціалу є Полтавська область.

Згідно з рейтингом Мінрегіону Полтавська область продовжує утримувати стійкі позиції в першій п'ятірці областей-лідерів за напрямами "Економічна ефективність", «Інвестиційний розвиток та зовнішньоекономічна співпраця", посідаючи 4 місце, а також посідає 6 місце за напрямом "Фінансова самодостатність». Завдяки значним темпам зростання надходжень до бюджетів усіх рівнів фрінансова спроможність Полтавщини дає можливість вирішувати широке коло соціально-економічних питань регіону [11].

Незважаючи на всі проблеми, Полтавська область має перспективні туристичні місця та події, які можна використати для розвитку туристичної галузі, зокрема музей-заповідник українського гончарства в Опішному, заповідник «Більськ», музей-заповідник М.В. Гоголя, Полтавський краєзнавчий музей імені Василя Кричевського та унікальної вишивки «білим по білому" з технікою виготовлення квіткових гобеленів у м. Решетилівці та інші заклади для розвитку пізнавального туризму; гастрономічні фестивалі Полтавщини, День Європи, "Гелон-фрест», Решетилівська весна, Купальські гуляння на батьківщині М.В. Гоголя для розвитку подієвого туризму; облаштовані конферецзали на базі Полтавського краєзнавчого музею імені Василя Кричевського, Історико-культур- ний заповідник «Більськ», Національний музейзаповідник М.В. Гоголя для розвитку ділового туризму; сільський зелений туризм можна розвивати на базі с. Більська, с. Кривої руди, с. Пивихи, м. Кременчука, смт. Нових Санжар, м. Миргорода, м. Хорола та м. Зінькова. Ці дані демонструють значний потенціал, на який може спиратися Полтавщина як потужна та органічна туристична дестинація.

Реалізацію державної політики в галузі туризму на території Полтавської області здійснює відділ із питань туризму і курортів облдержадміністрації. Відповідно до вимог Законів України «Про туризм», «Про курорти» було розроблено та створено комплексну програму розвитку культури, мистецтва та охорони культурної спадщини в Полтавській області на 2018-2020 роки (2017 рік), обласну програму розвитку туризму і курортів на 2016-2020 роки (2016 рік), програму збереження, вивчення та популяризації Більського городища на період 2018-2022 років (2017 рік).

Україну відвідує досить значна кількість туристів, хоча з приватними цілями, а громадяни нашої країни віддають перевагу іноземним курортам. Подібна ситуація характерна, зокрема, для туристичної галузі Полтавської області (рис. 1, 2).

3 цих рисунків видно, що туристичні потоки в Полтавській області за 2000-2018 роки є мінливими, що безпосередньо пов'язано 3 подіями, які сталися у 2014 році. Протягом 2000 року спостерігаємо спад туристичних потоків до 2001 року на 37\%. За 2000-2005 роки туристичні потоки в Полтавській області мали тенденцію збільшення до 2003 року та зменшення до 2005 року. 32005 по 2008 роки спостерігалося збільшення туристичних потоків, а протягом 2010, 2011, 2012, 2013 і 2014 років зменшення $(24,0 \% ; 62,5 \% ; 51,7 \% ; 64,4 \% ; 87,1 \%$ відповідно) порівняно з 2005 роком. Зменшилась також кількість іноземних туристів упродовж 2005-2014 років з 2104 осіб у 2005 році до 87 осіб у 2014 році, що на 95,9\% менше. Далі поступове збільшення туристичних потоків можна спостерігати з 2016 року. Кількість в'їзних (іноземних) туристів за 2000-2008 роки зросла на 986 осіб, за 2008-2018 роки - на 150 осіб. За весь період абсолютний приріст становить 1136 осіб.

За 2000-2008 роки кількість в'їзних (іноземних) туристів збільшилась у 3,7 разів, за 2008-2018 роки - в 1,1 рази. Базовий темп зростання за весь період становить 4,2 рази. Темпи приросту є ланцюговими за 2000-2008 роки $(270 \%)$, за 2008-2018 роки (10\%); базовий становить $320 \%$. Кількість туристів - громадян України, які виїздили за кордон, перевищила 


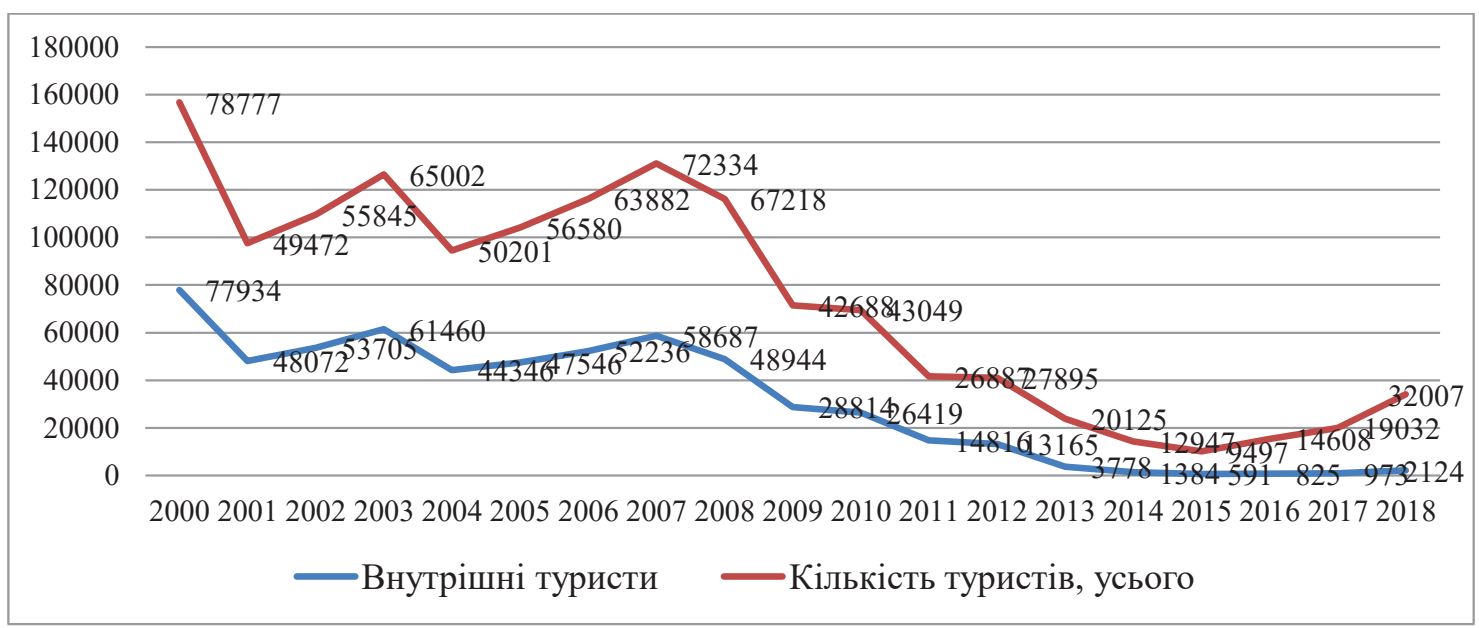

Рис. 1. Кількість туристів, обслугованих туроператорами та турагентами за 2000-2018 роки в Полтавській області (осіб) [11]

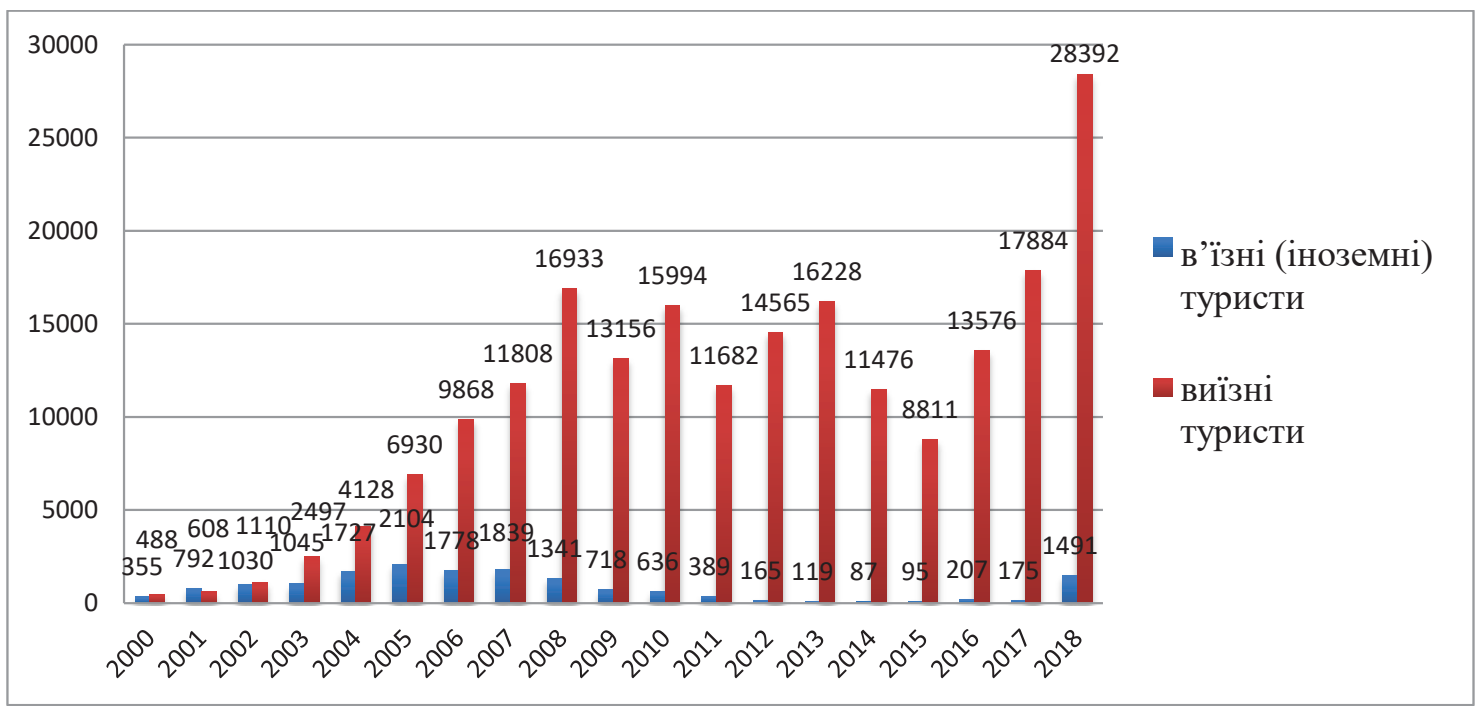

Рис. 2. Кількість в'їзних (іноземних) та виїзних туристів за 2000-2018 роки в Полтавській області (осіб) [11]

кількість обслужених іноземних туристів у 2018 році більш ніж у 19 разів.

Отже, одним з основних завдань туристичної галузі України та Полтавської області $€$ активізація вивчення попиту споживачів для більш тісної співпраці з виробниками туристичних послуг щодо забезпечення високого рівня задоволення потреб споживачів та залучення їх до внутрішнього туризму.

Основними проблемами туристичного розвитку Полтавщини є:

1) низький рівень використання туристичного потенціалу території;

2) відсутність іміджу сучасного туристично привабливого регіону;

3) невикористання промислових комплексів та індустріальної спадщини області для повноцінного розвитку інноваційних напрямів туризму, зокрема індустріального та ділового туризму;

4) недостатня розвиненість туристичної інфрраструктури області;

5) низька якість комерційних та окремих комунальних послуг;

6) незацікавленість приватних інвесторів у розвитку туристичної галузі.

Задля визначення основних чинників впливу та фрормулювання стратегічних напрямів розвитку туристичної галузі Полтавської області було застосовано SWOT-аналіз (табл. 1) [12].

Висновки з проведеного дослідження. Вирішення проблем передбачає перш за все створення дієвого механізму, який повинен забезпечувати своєчасне прийняття ефективних рішень на всіх етапах управлінського циклу, якими $€$ планування, постановка завдань, організація 
Таблиця 1

SWOT-аналіз туристичної галузі Полтавської області

\begin{tabular}{|c|c|}
\hline Сильні сторони & Слабкі сторони \\
\hline $\begin{array}{l}\text { 1) Унікальна історична й культурна спадщина; } \\
\text { 2) економічно розвинений регіон; } \\
\text { 3) вигідне транспортно-логістичне розташування } \\
\text { (автошляхи та залізничні шляхи); } \\
\text { 4) наявність значної кількості об'єктів і територій } \\
\text { заповідного фонду; } \\
\text { 5) власні енергетичні, промислові, будівельні } \\
\text { потужності; } \\
\text { 6) досить високий рівень концентрації людського } \\
\text { капіталу, наявність наукових закладів та } \\
\text { студентської молоді. }\end{array}$ & $\begin{array}{l}\text { 1) Низька якість комерційних та окремих } \\
\text { комунальних та муніципальних послуг; } \\
\text { 2) проблеми з благоустроїм потенційно } \\
\text { привабливих туристичних об'єктів; } \\
\text { 3) низька якість та недостатній асортимент } \\
\text { туристичних послуг; } \\
\text { 4) низька активність у сфері туризму, послуг, } \\
\text { розвитку клієнтоорієнтованого малого та } \\
\text { середнього бізнесу; } \\
\text { 5) низький рівень кооперації, партнерських } \\
\text { відносин, кластеризації сфери послуг; } \\
\text { 6) недостатня кількість професійних кадрів у } \\
\text { системі управління. }\end{array}$ \\
\hline & \\
\hline $\begin{array}{l}\text { 1) Доступність сучасних інформаційних } \\
\text { технологій та їхній подальший розвиток; } \\
\text { 2) збільшення попиту на туристичні продукти на } \\
\text { внутрішньому ринку; } \\
\text { 3) близькість обласних центрів та інших } \\
\text { населених пунктів із загальною чисельністю } \\
\text { понад } 10 \text { млн. осіб; } \\
\text { 4) зацікавленість історико-культурною } \\
\text { спадщиною з боку української діаспори та } \\
\text { зарубіжних представників інших національних } \\
\text { меншин; } \\
\text { 5) альтернативні джерела фрінансування проєктів } \\
\text { (фонди підтримки, грантові програми, проєкти } \\
\text { міжнародної технічної допомоги); } \\
\text { 6) наявність постійного попиту з боку жителів } \\
\text { області у сфрері пізнавального, подієвого, } \\
\text { промислового, сільського зеленого туризму. }\end{array}$ & $\begin{array}{l}\text { 1) Неналежний стан транспортної } \\
\text { інфраструктури країни, низька якість послуг } \\
\text { з перевезення; } \\
\text { 2) дефріцит бюджету, неможливість } \\
\text { фрінансування проєктів через нерівноцінний } \\
\text { розподіл бюджету "центр-регіони»; } \\
\text { 3) конкуренція з боку інших міст і регіонів } \\
\text { України; } \\
\text { 4) неефрективне державне управління } \\
\text { туристичною галуззю загалом; } \\
\text { 5) поглиблення макроекономічних кризових } \\
\text { явищ на національному та світовому ринках; } \\
\text { 6) відсутність підтримки ініціатив місцевої } \\
\text { влади у сорері розвитку туризму з боку } \\
\text { бізнесу та громадськості, центральних } \\
\text { органів влади. }\end{array}$ \\
\hline
\end{tabular}

виконання, забезпечення ресурсами, управління ризиками, контроль виконання, моніторинг та оцінювання результатів впровадження стратегічних рекомендацій, а також подальше регулювання процесу й актуалізація цілей.

Зарубіжний досвід свідчить про те, що важливу роль у регулюванні діяльності підприємств туристичного сектору в регіонах відіграє створення регіональної управлінської організаційної структури. Основними напрямами механізму регіонального управління розвитком туризму мають стати удосконалення механізмів регулювання господарської діяльності з урахуванням досвіду країн із розвиненою туристичною галуззю; створення цільових програм розвитку туризму на рівні регіонів; фрормування стратегії розвитку туризму та розроблення конкретних заходів щодо досягнення поставленої стратегічної мети.

Специфічними стратегічними результатами безпосередньо у сфері туризму, на досягнення яких спрямовуються зусилля влади, бізнесу й громади області під час розроблення та реалізації стратегій, мають бути:
1) закріплення Полтавщини в п'ятірці найбільш відвідуваних туристами регіонів України;

2) формування стабільного в'їзного потоку туристів до області [12].

Україна вибрала своїм стратегічним курсом інтеграцію до структур Європейського Союзу. Для досягнення цієї мети потрібно виконати низку умов, однією з найголовніших серед яких $є$ активний регіональний розвиток. Потрібно розробити стратегічні рекомендації щодо вдосконалення державного регулювання розвитку туризму та стимулювання його фінансово-ресурсного забезпечення в Полтавській області. Отже, слід:

- удосконалити організаційну структуру з управління розвитком туристичної галузі Полтавської області та організувати її діяльність;

- покращити організаційну, кадрову, правову, матеріально-технічну та іншу ресурсну підтримку туристичної сорери області;

- створити систему фрінансового забезпечення розвитку туристичної галузі;

- активізувати співпрацю з іншими містами, регіонами, країнами у сфері розвитку туризму, 
розширити міжнародні та міжкультурні зв'язки;

- покращити загальний благоустрій, дотри-

мання санітарних і будівельних норм на території регіону для підвищення туристичної привабливості області;

- удосконалити транспортну інфрраструктуру регіону;

- створити сучасні території відпочинку й рекреації на базі природно-ландшафтного потенціалу регіону;

- забезпечити досягнення якості муніципальних та комерційних послуг європейського рівня;

- запровадити цілеспрямовану політику маркетингу й орормування іміджу Полтавщини як регіону, відкритого для туристів;

- активізувати маркетингову підтримку розвитку туристичної галузі;
- сприяти актуалізації нових напрямів розвитку туристичної галузі області, таких як подієвий, пізнавальний та сільський зелений туризм.

Таким чином, можна констатувати, що в Україні активно фрормується новітній рівень в організації туристичної галузі, відповідно, виникає необхідність створення дієвого механізму управління ним. Це питання є особливо актуальним у зв'язку з побудовою структури Державної служби туризму і курортів. Запропонована модель удосконалення організаційної структури управління, заснованої на використанні регіонального підходу, має як переваги, так і недоліки, безумовно, потребує подальшого дослідження щодо розроблення уніфікованих критеріїв для визначення певної території туристичним регіоном, структурних підрозділів, фрінансування тощо.

\section{Список використаних джерел:}

1. Семенов В.Ф. Державне регулювання та управління регіональним розвитком туризму. Економіка і управління. 2010. № 1. С. 40-44.

2. Галасюк С.С. Необхідність удосконалення державного регулювання сорери туризму України. 2007. URL: http://dspace.oneu.edu.ua/jspui/bitstream/123456789/315/1/Необхідність\%20удосконалення\%20державного\%20регулювання\%20сфрери\%20туризму\%20в\%20Україні.pdf (дата звернення: 29.09.2019).

3. Алєксєєва Ю.В. Державне регулювання соціального туризму в Україні. Збірник наукових праць НАДУ. 2009. Вип. 1. С. 182-191.

4. Бережная И.В., Захарова О.Д. Теоретические аспекти определения зкономической сущности понятия «региональная система» в контексте регионализации зкономики. Экономика и управление. 2007. № 1. С. 46-50.

5. Круглов М.И. Стратегическое управление компанией. Москва : Русская деловая литература, 1998. 768 c.

6. Фокін С.П. Туризм: питання термінологічного апарату. Формування стратегії сталого розвитку курортів в Україні : матеріали всеукраїнського «круглого столу» (Київ, 26 червня 2007 року). Сімферополь : ВАТ «Сімферопольська міська друкарня» (СГТ), 2007. С. 127-134.

7. Загорянська О.Л., Антоненко Р.І. Досвід створення сучасних систем менеджменту якості. Актуальні проблеми та перспективи розвитку економіки в умовах глобальної нестабільності : збірник матеріалів міжнародної науково-практичної конференції. Кременчук : КрНУ, 2013. C. 131-132.

8. Бабарицька В.К., Малиновська О.Ю. Менеджмент туризму. Туроперейтинг. Понятійно-термінологічні основи, сервісне забезпечення турпродукту : навчальний посібник. Київ : Альтерпрес, 2004. 288 с.

9. Валентюк І.В. Організаційно-економічні механізми державного регулювання туристичної сорери України : автореф. дис. ... канд. наук з держ. упр. : спец. 25.00.02. Київ, 2005. 19 с.

10. Сакун Л.М., Сосновська Ю.Р. Теоретико-прикладні аспекти розвитку регіонального туризму. Перспективи розвитку туристичної індустрії в Україні: регіональні аспекти : збірник матеріалів III Всеукраїнської науково-практичної інтернет-конференції. Умань : УДПУ, 2015. С. 59-61.

11. Головне управління статистики у Полтавській області. URL: http://www.pl.ukrstat.gov.ua (дата звернення: 29.09.2019).

12. Стратегія розвитку туризму та курортів у Полтавській області на 2019-2029 роки // Пленарне засідання двадцять третьої сесії сьомого скликання «Про затвердження Стратегії розвитку туризму та курортів у Полтавській області на 2019-2029 роки», 21 грудня 2018 року. № 972.31 с.

\section{References:}

1. Semenov V.F. (2010) Derzhavne rehuliuvannia ta upravlinnia rehionalnym rozvytkom turyzmu [State regulation and management of regional tourism development]. Ekonomika i upravlinnia [Economics and Management], no. 1, pp. 40-44.

2. Halasiuk S.S. (2007) Neobkhidnist udoskonalennia derzhavnoho rehuliuvannia sfery turyzmu Ukrainy [The need to improve state regulation of tourism in Ukraine]. Available at: http://dspace.oneu. 
edu.ua/jspui/bitstream/123456789/315/1/Необхідність\%20удосконалення\%20державного\%20 регулювання\%20сфери\%20туризму\%20в\%20Україні.pdf (accessed: 29.09.2019).

3. Alieksieieva Yu.V. (2009) Derzhavne rehuliuvannia sotsialnoho turyzmu v Ukraini [State regulation of social tourism in Ukraine]. Proceedings of the NADU, vol. 1, pp. 182-191.

4. Berezhnaia Y.V., Zakharova O.D. (2007) Teoretycheskye aspekty opredelenyia zkonomycheskoi sushchnosty poniatyia "rehyonalnaia systema" v kontekste rehyonalyzatsyy zkonomyky [Theoretical aspects of the definition of economic essence of the concept of "regional system" in the context of regionalization of the economy]. Ekonomika i upravlinnia [Economics and Management], no. 1, pp. 46-50.

5. Kruhlov M.Y. (1998) Stratehycheskoe upravlenye kompanyei [Strategic management of the company]. Moscow : Russian business literature (in Russian).

6. Fokin S.P. (2007) Turyzm: pytannia terminolohichnoho aparatu [Tourism: issues of terminology]. Proceedings of the Formuvannia stratehii staloho rozvytku kurortiv v Ukraini (Ukraine, Kyiv, June 26, 2007). Simferopol : VAT "Simferopolska miska drukarnia" (SHT), pp. 127-134.

7. Zahorianska O.L., Antonenko R.I. (2013) Dosvid stvorennia suchasnykh system menedzhmentu yakosti [Experience in creating modern quality management systems]. Proceedings of the Aktualni problemy ta perspektyvy rozvytku ekonomiky $v$ umovakh hlobalnoi nestabilnosti (Ukraine, Kremenchuk, 2013), KrNU, pp. 131-132.

8. Babarytska V.K., Malynovska O.Yu. (2004) Menedzhment turyzmu. Turopereitynh. Poniatiino-terminolohichni osnovy, servisne zabezpechennia turproduktu [Tourism management. Touring. Conceptual and terminological bases, service of the tourist product]. Kyiv : Alter-pres (in Ukrainian).

9. Valentiuk I.V. (2005) Orhanizatsiino-ekonomichni mekhanizmy derzhavnoho rehuliuvannia turystychnoi sfery Ukrainy [Organizational and economic mechanisms of state regulation of the tourist sphere of Ukraine] (PhD Thesis), Kyiv : National Academy of Public Administration at the President of Ukraine.

10. Sakun L.M., Sosnovska Yu.R. (2015) Teoretyko-prykladni aspekty rozvytku rehionalnoho turyzmu [Theoretical and applied aspects of regional tourism development]. Proceedings of the Perspektyvy rozvytku turystychnoi industrii v Ukraini: rehionalni aspekty (Ukraine, Uman, 2015), Uman : UDPU, pp. 59-61.

11. Holovne upravlinnia statystyky u Poltavskii oblasti [Main Department of Statistics in Poltava Oblast]. Available at: http://www.pl.ukrstat.gov.ua (accessed: 29.09.2019).

12. Stratehiia rozvytku turyzmu ta kurortiv u Poltavskii oblasti na 2019-2029 roky [Strategy of tourism and resort development in Poltava region for 2019-2029]. Proceedings of the Pro zatverdzhennia Stratehii rozvytku turyzmu ta kurortiv u Poltavskii oblasti na 2019-2029 roky (Ukraine, Poltava, December 21, 2018), no. 972, pp. 31. 